\title{
Integrasi Kegiatan Masyarakat Budaya Lokal dan Lembaga dalam Pendidikan Toleransi
}

\author{
Jazuli Mukhtar \\ Universitas Pamulang (UNPAM), Indonesia \\ Email: dosen00292@unpam.ac.id \\ Yunus \\ Universitas Pamulang (UNPAM), Indonesia \\ Email: nurhang542@gmail.com \\ Ichwan Nugroho \\ Universitas Pamulang (UNPAM), Indonesia \\ Email: ichwan.nugroho@yahoo.co.id
}

\begin{abstract}
The research explains the form of local wisdom of Bugis culture as a cultural value that characterizes the Palopo people. The local wisdom developed in Palopo City is in line with the pluralistic Palopo culture developing in Indonesia. Palopo people has local wisdom values such as humanizing. These values are always preserved so that they become the glue of religious harmony in Palopo City. The type of this research is ethnography. The research findings show that knowledge and understanding of the cultural traditions of society that contain pluralism allow students to suspend suspicion or even wholly disappear negative things that students have understood about other religions. The concept of pluralism is seen from implementing the cultural philosophy in Palopo, namely Sipakatau, Sipakalebbi, and Sipakaingge. Two universities, IAIN Palopo and Andi Djemma University practice the local wisdom values. The results shows that personally, students who were actively involved in the implementation of local wisdom education felt that they had experienced significant changes. In the aspect of faith, they are increasingly convinced of their religion while still providing adequate space for a good and correct assessment of the truth of the teachings of other religious and cultural beliefs.
\end{abstract}

\section{Keywords: Local Wisdom, Education, Tolerance}

\begin{abstract}
Abstrak
Penelitian menjelaskan wujud kearifan lokal budaya Bugis sebagai nilai budaya yang menjadi ciri khas masyarakat Palopo. Kearifan lokal yang berkembang di Kota Palopo sejalan dengan pluralistik budaya Palopo yang berkembang di Indonesia. Kota Palopo memiliki nilai kearifan lokal seperti memanusiakan. Nilai-nilai tersebut selalu dilestarikan, sehingga menjadi perekat kerukunan umat beragama di Kota Palopo. Jenis penelitian ini adalah etnografi. Temuan penelitian bahwa pengetahuan dan pemahaman terhadap tradisi budaya masyarakat yang mengandung nilai pluralisme memungkinkan mahasiswa untuk bisa menunda kecurigaan, atau bahkan menghilangkan hal-hal negatif yang selama ini dipahami oleh mahasiswa terhadap agama lain. Konsep pluralisme dilihat dari implementasikan dari filosofi budaya di Kota Palopo yakni Sipakatau, Sipakalebbi dan Sipakaingge. Nilai-nilai kearifan lokal yang dipraktikkan oleh IAIN Palopo dan Universitas Andi Djemma. Hasil analisis menunjukkan bahwa secara personal mahasiswa yang terlibat aktif di dalam pelaksanaan pendidikan kearifan lokal ini merasa mengalami perubahan. Pada aspek iman, mereka semakin yakin dengan agamanya sendiri, sembari tetap memberi ruang yang adil terhadap penilaian yang baik dan benar terhadap kebenaran ajaran keyakinan agama dan budaya lain.
\end{abstract}

Kata Kunci: Kearifan Lokal, Pendidikan, Toleransi 


\section{Jazuli Mukhtar, Yunus, dan Ichwan Nugroho: Integrasi Kegiatan Masyarakat Budaya}

Lokal dan Lembaga dalam Pendidikan Toleransi

\section{A. Pendahuluan}

Kota Palopo merupakan salah satu kota yang berada di Provinsi Sulawesi Selatan yang penduduk dan agamanya sangat majemuk. Penduduk kota Palopo terdiri dari beragam suku seperti suku Bugis, Toraja, Jawa, Bali, Madura, dan Sunda, dengan agama yang bermacam pula seperti Islam, Nasrani, Hindu, dan Budha. Suku Jawa, Sunda dan Bali yang merupakan angkatan transmigrasi di tahun 1980-an serta pada masa penjajahan merupakan tenaga rodi Belanda di tahun 1930-an yang hingga kini menjadi penduduk tetap yang ikut membangun dan memajukan daerah Luwu. ${ }^{1}$ Walaupun orang sering mengatakan bahwa Luwu termasuk suku Bugis, tetapi orang-orang Luwu itu sendiri menyatakan mereka bukan suku Bugis, tetapi orang Luwu.

Posisi adat dalam masyarakat Kota Palopo memiliki posisi yang khas. Pergulatan pemikiran Islam Indonesia tidak dapat melepaskan diri dari aspek adat sebagai bagian penting. Sebagaimana kajian Adlin Sila di masyarakat Jawa bahwa tidak memungkinkan untuk melakukan klaim Islam Indonesia dengan hanya semata-mata melihat satu suku atau etnis saja. ${ }^{2}$ Sementara, pola perjumpaan adat dan Islam menemukan bentuk dalam beberapa gambaran seperti di Minangkabau yang mengalami konflik antara keinginan untuk mempertahankan adat dengan penerimaan Islam sebagai agama dan jalan hidup. ${ }^{3}$ Adapun dalam tradisi Aceh adat berjalan paralel dengan praktik beragama. ${ }^{4}$ Ini menunjukkan adanya proses transformasi agama ke dalam adat dengan respon yang berbeda-beda. ${ }^{5}$ Agama di satu sisi merupakan sistem keyakinan yang dianut dan diwujudkan oleh penganutnya dalam tindakan-tindakan keagamaan di masyarakat dalam upaya memberi respon dari apa yang dirasakan dan diyakini sebagai suatu yang sakral dan suci. Pada sisi yang lain agama juga mengandung ajaran yang menanamkan nilai-nilai sosial pada penganutnya sehingga ajaran agama tersebut merupakan suatu elemen yang membentuk sistem nilai budaya.

Nilai-nilai sosial menurut Khaled Abou el-Fadl adalah semangat toleran dan pluralis dari para penganut agama akan menentukan corak pemahaman teks suci agama tersebut secara toleran pula. ${ }^{6}$ Dengan demikian, signifikansi atau peran para tokoh agama dalam memberikan pemahaman keagamaan kepada para penganut agama menjadi sangat signifikan, apakah pemahaman yang diberikan itu eksklusif ataukah inklusif.

Berbagai pandangan tentang pentingnya toleransi, terimplementasi dengan baik di kota Palopo, sehingga ketegangan semakin berkurang, dan peran pemerintah kota Palopo begitu intends dalam menyosialisasikan serta memberi pemahaman tentang pentingnya saling

${ }^{1}$ Yunus, Y., \& Mukhlisin. (2020). Sosial-Budaya: Harmonisasi Agama dan Budaya dalam Pendidikan Toleransi. Kalam: Jurnal Agama Dan Sosial Humaniora, 8(2), 1-26.

${ }^{2}$ Kamaruzzaman Bustaman-Ahmad, "Contemporary Islamic Thought in Indonesia and Malay World: Islam Liberal, Islam Hadhari, and Islam Progresif”, Journal of Indonesian Islam, Vol. 5, (1) (June 2011): 91. Lihat Sheetal R. Shah, The Impact of Acculturation and Religion on Intergenerational Family Conflict for Second Generation Asian Indian Americans, Tesis (Carbondale: Southern Illinois University, 2006). Lihat Meike Watzlawik, "Cultural Identity Markers and Identity as a Whole: Some Alternative Solutions", Culture and Psychology, Vol. 18, (2), (2012): 253-260.

${ }^{3}$ Adlin Sila, "Memahami Spektrum Islam di Jawa", Indonesian Journal for Islamic Studies Studia Islamika, Vol. 18, (3), (2011): 611.

${ }^{4}$ Taufik Abdullah, "Adat and Islam: An Examination of Conflict in Minangkabau”, Indonesia, No. 2 (1966): 1. Lihat Za'im Rais, "The Minangkabau Traditionalists' Response to The Modernist Movement", disertasi (Montreal: McGill University, 1994).

${ }^{5}$ Stephen Todd dan Andrew Steele, "Modelling a Culturally Sensitive Approach to Fuel Poverty", Structural Survey, Vol. 24, (4), (2006): 300-310.

${ }^{6}$ Khaled Abou el-Fadl secara jelas menyebut bahwa "makna sebuah teks suci kerap kali bergantung pada moral pembacanya. Jika pembacanya intoleran dan penuh kebencian, maka demikianlah hasil penafsiran atas teks tersebut. Selengkapnya baca Khaled Abou el-Fadl, The Place of Tolerance in Islam (Boston: Beacon Press, 2002$), 23$. Lihat Ibrahim Kali>n, "Masa>dir al-Tasa>muh\}, wa'adam al-Tasa>muh fi al-Islam", Majalah Adyan (2009): 2632. Saleh Saidi et al., eds., Sejarah Keberadaan Umat Islam di Bali, (Denpasar: MUI, 2002). 
menghormati dan menghargai dalam keragaman melalui pemanfaatan pranata-pranata sosial, seperti kebudayaan, lembaga pendidikan, lembaga adat, serta organisasi-organisasi kemasyarakatan lainnya, terlebih lagi jika dilihat dari sejarahnya, suku Toraja (Kristen) dan Islam di Tana Luwu (Kota Palopo) sangat menjunjung toleransi beragama dan bermasyarakat.

Menurut Wynne, dunia perguruan tinggi merupakan tempat menyemai, mendidik dan melatih mahasiswa agar menjadi mahasiswa yang memiliki daya nalar tinggi, analisis tajam dan luas. ${ }^{7}$ Sayangnya, perguruan tinggi kurang memberikan porsi pada pembentukan karakter mahasiswa. Bahkan, Arthur menyatakan jika perguruan tinggi menjanjikan pembentukan dan pengembangan karakter mahasiswa seperti yang terjadi di Inggris, semua itu hanya retorika institusi universitas modern. Sementara itu, Syukri asyarakat Indonesia masih menaruh harapan pada perguruan tinggi sebagai tempat latihan dan pendidikan putra putrinya menjadi kaum intelektual yang memiliki ilmu tinggi dan perilaku terpuji. ${ }^{8}$

Ironisnya tak ada perguruan tinggi yang menjamin lulusannya memiliki moral etika yang baik. Di sisi lain, misi perguruan tinggi adalah pengajaran, penelitian dan aplikasi ilmu pengetahuan, ${ }^{9}$ sehingga secara eksplisit pembentukan karakter dianggap bukan merupakan tugas perguruan tinggi. Oleh karena itu implementasi pendidikan karakter di perguruan tinggi akan menemui tantangan tersendiri. Schwartz menyatakan beberapa hal yang menyebabkan pendidikan karakter di perguruan tinggi akan menemui kendala karena adanya pendapat yang keliru yaitu karakter seseorang sudah terbentuk sebelum masuk ke perguruan tinggi dan merupakan tanggung jawab orangtua untuk membentuk karakter anaknya. Perguruan tinggi, khususnya dosen, tidak memiliki kepentingan dengan pembentukan karakter, karena mereka direkrut bukan untuk melakukan hal tersebut. Karakter merupakan istilah yang mengacu pada agama atau idiologi konservatif tertentu, sementara itu perguruan tinggi di barat secara umum melepaskan diri dari agama atau idiologi tertentu. ${ }^{10}$ Keengganan perguruan tinggi di Barat seperti Inggris dan Amerika Serikat, mengurus masalah moral antara lain karena masalah moral merupakan wilayah pribadi dan mereka dipengaruhi oleh idiologi liberal yang telah menjadi gaya hidup.

Penulis berasumsi bahwa ada 4 alasan perguruan tinggi yang tidak menaruh perhatian pada pembentukan moral mahasiswa, yaitu: 1) Takut dengan tuntutan berbagai macam karakter dan perilaku mahasiswa untuk mendapatkan pembinaan; 2) Menjalankan pendidikan sesuai dengan kebijakan politik pemerintah; 3) Mahasiswa diarahkan menjadi warga Negara yang demokratis; dan 4) Perguruan tinggi mengembangkan karakter sesuai dengan tuntutan pasar dan jaringan. Walaupun demikian, menurut penulis perguruan tinggi tidak boleh lepas lepas tanggung jawab dengan alasan apapun termasuk menganggap bahwa karakter sudah terbentuk sebelum mahasiswa masuk perguruan tinggi, merupakan tanggung jawab orangtua dan institusi pendidikan di tingkat bawahnya, apalagi dengan alasan beban berat menghasilkan lulusan sesuai tuntutan pasar.

Untuk mewujudkan pembentukan karakter Schwartz menyatakan bahwa universitas baik yang berlatar belakang agama maupun yang sekuler, dapat menggunakan kekuatan kurikulumnya, khususnya efek baiknya, untuk membentuk pemikiran tetapi juga karakternya. Kurikulum ini tidak saja membentuk intelectual habits namun juga moral habits mahasiswa. Dengan demikian, jika perguruan tinggi tidak menyusun program pendidikan karakter

${ }^{7}$ Wynne, E. A., and K. Ryan. Reclaiming our schools: A handbook on teaching character, academics, and discipline, (New York: Merrill, 1993).

${ }^{8}$ Syukri, Peran Pendidikan di Perguruan Tinggi terhadap Perubahan Perilaku Kaum Intelektual (sosialIndividu). Jurnal Ilmiah Kreatif, vol 6 no 1, (2009): h. 1-15.

${ }^{9}$ Stiff-William, HR. Widening Lens to Teach Character Education Alongside Standart Curriculum. Abstract. The Clearing House, Vol 83. (4) (2010):115-120.

${ }^{10}$ Schwartz, It's Not to Late to Teach College Student about Values. The Chronicle of Higher Education. Vol 46. (40), (2000): 68. 
tersendiri namun mengintegrasikannya kedalam kurikulum standar yang sudah ada, maka yang perlu dilakukan adalah meninjau kembali muatan mata kuliah pengembangan kepribadian dan mengembalikannya ke arah pembentukan karakter sesuai amanat Undang-undang Sisdiknas.

Oleh karenanya, diperlukan tindakan untuk mengangkat kembali nilai-nilai kearifan lokal sebagai sumber inovasi dalam bidang pendidikan berbasis budaya masyarakat lokal, ${ }^{11}$ dengan cara melakukan pemberdayaan melalui adaptasi pengetahuan lokal, termasuk reinterpretasi nilai-nilai kearifan lokal, dan revitalisasinya sesuai dengan kondisi kontemporer. Selain itu diperlukan kerjasama yang kuat antara pemerintah daerah, perguruan tinggi dan budayawan untuk revitalisasi nilai-nilai kearifan lokal maupun mengembangkan konsepkonsep akademik, melakukan uji coba model-model etnopedagogi dalam pembelajaran. ${ }^{12}$

Ide-ide tersebut mengandung nilai-nilai yang memengaruhi pendukungnya ketika dalam situasi tertentu mereka mengambil keputusan. Nilai-nilai itu merupakan warisan budaya karena dimiliki dan ditaati, dihormati dan dihargai, serta dibela dan dipertahankan oleh masyarakatnya. Dalam tradisi Bugis, pelanggaran atas nilai-nilai tradisi menimbulkan konsekuensi runtuhnya kehormatan pribadi, baik dalam keluarga maupun masyarakat. ${ }^{13}$ Untuk menciptakan kondisi yang toleran dalam masyarakat kota Palopo pada umumnya (Bugis) pada zaman dahulu diidentikkan dengan konsep assimellereng yang terdapat dalam pangaderreng yang kini menjadi prinsip paling dijunjung dalam kehidupan sehari-hari. ${ }^{14}$

Pentingnya artikel membuktikan bantahan terhadap pendapat dan argumen yang dikemukankan oleh Michalinos Zembylas dan Zvi Bekerman, lewat pembaharuan pendidikan yaitu melalui penerapan pendidikan pluralisme, diharapkan dapat merangkul seluruh kemajemukan yang ada. Dengan penerapan pengamalan pendidikan karakter yang diintregasikan dengan budaya serta kearifan lokal setempat, yang selanjutnya akan menghasilkan sebuah pendidikan karakter berbasis kearifan lokal yang tidak saja menghasilkan mahasiswa yang saleh secara individual, tetapi juga menciptakan mahasiswa yang saleh secara publik.

Ketika penganut agama secara produktif menempatkan kearifan lokal dan Islam secara bersama-sama dengan budaya, maka justru dapat mendorong ke arah kesatuan untuk menempatkan agama sebagai suatu yang suci. Sementara kearifan lokal menjadi sarana untuk menjembatani kepercayaan yang ada. Ini terjadi dalam praktik pendidikan yang mengedepankan pertautan antara agama dan tradisi, sehingga menghasilkan produktivitas dalam bentuk sosial. ${ }^{15}$ Dengan penanaman moral keagamaan yang baik, maka pasti akan diikuti dengan terbangunnya tradisi yang baik juga. Sehingga penelitian ini, merujuk pada kombinasi Lembaga pendidikan sebagai pelaksana kearifan lokal dikampus, namun mempunyai dampak kepada masyarakat khusus di Kota Palopo.

\footnotetext{
${ }^{11}$ Sri Mulyani, "Islam, Adat, and the State: Matrifocality in Aceh Revisited", Journal of Islamic Studies al-Jamiah, Vol. 48, (2) (2010/1431): 321-342.

${ }^{12}$ Stephen Todd dan Andrew Steele, "Modelling a Culturally Sensitive Approach to Fuel Poverty", Structural Survey, Vol. 24, (4), (2006): 300.

${ }^{13}$ Hilmi Muhammadiyah, Perempuan Bugis Naik Haji-Sebuah Tinjauan Antropologis (Depok: Elsas, 2009), 3.

${ }^{14}$ B. F. Matthes, Over de Ada's of Gewoonten der Makassaren en Boegineezen, (tth) 2. George P. Moschis, Fon Sim Ong, Masoud Abessi, Takako Yamashita, dan Anil Mathur, "Cultural and Sub-Cultural Differences in Reliability", Asia Pacific Journal of Marketing and Logistics, Vol. 25, (1) (2013): 34. Naskah ini termaktub dalam "Poada-adaengngi bicarana Latoa", B. F. Matthes, Boeginesche Chrestomathie (Amsterdam: 1859), 57. Secara lengkap dalam bahasa Bugis tertulis "iko pakkatenni ade'e isseng majeppu I riasenge ade': muwawatutuiwi, mupakarajai, apa' ade'e ritu riaseng tau. Nakko temmuissengngi riasenge ade' tencaji ritu tauwe riaseng tau. Apa' de'tu appongenna ade'e sangadinna ianaritu tau'e ti dewatae namatanre siri' ianaritu tau temmasarang lempu'e". Robert N. Bellah dan Phillip E. Hammond, Varieties of Civil religion (Yogyakarta: IRCiSoD, 2003), 10.

${ }^{15}$ W. E. Garah, R. I. Beekun, A. Habisch, G. Lenssen, C. L. Adaui, "Practical Wisdom for Management from the Islamic Tradition”, Journal of Management Development, 31, (10), (2012): 991-1000.
} 


\section{B. Hasil Temuan}

Berdasarkan hasil penelitian pada perguruan tinggi di kota Palopo, yaitu Universitas Andi Djemma dan IAIN Palopo, perguruan tinggi menggunakan beberapa model pendidikan pluralisme agama yang dapat di melerai konflik suku di Tana Luwu khusus Kota Palopo.

\section{B.1. Model Kontribusi}

Model pembelajaran ini, mahasiswa mampu terciptanya toleransi, empati, kasih sayang, kebersamaan, menghargai perbedaan, tolong menolong, sopan santun, luwes, tenggang rasa, kekeluargaan, yang dalam implementasinya, mahasiswa disertakan untuk memilih bacaan bersama sekaligus melakukan aktivitas bersama. Selain itu juga, peserta didik diajak untuk mengapresiasi event-event keagamaan maupun kebudayaan dari berbagai agama dan kebudayaan warga sekolah yang berbeda-beda.

Indikator pencapaian dari penggunaan model pembelajaran ini adalah; Pertama, menunjukkan sikap jujur dalam bertutur kata dan berinteraksi dengan sesama; Kedua, menunjukkan sikap hormat dan patuh kepada kedua orang tua dan guru; Ketiga, bersikap sopan dan santun dalam pergaulan di lingkungan keluarga, sekolah, dan masyarakat; Keempat, mengembangkan budaya toleransi dengan didasarkan pada konsep agama dan budaya daerah; Kelima, dapat bekerja sama serta memberikan kontribusi positif kepada orang yang berbeda agama, suku, ras dan golongan.

\section{B.2. Model Pengayaan}

Model pendidikan ini bertujuan untuk memperkaya kurikulum dengan literatur dari atau masyarakat yang berbeda budaya, etnis, dan agama. Dalam implementasinya, peserta didik diajak untuk menilai atau menguji dan kemudian mengapresiasikan cara pandang warga sekolah terhadap tradisi agama dan budayanya masing-masing. Dalam proses pembelajaran Pendidikan Agama Islam di perguruan tinggi, ia lebih mengedepankan pada proses konstruksi pembelajaran berdasarkan pada keberagamaan yang inklusif. ${ }^{16}$ Pemberian materi pelajaran Pendidikan Agama Islam, dikembangkan olehnya dengan nuansa plural-multikultural yang disesuaikan dengan konteks di Kota Palopo dan Tana Luwu pada umumnya

\section{B.3. Model Pembuatan Keputusan dan Aksi Sosial}

Model pendidikan ini sebenarnya merupakan pengintegrasian antara model kontribusi dan model pengayaan dengan aktivitas nyata warga sekolah yang pada gilirannya bisa berdampak pada terjadinya interaksi sosial di masyarakat secara umum. Peserta didik tidak hanya dituntut untuk memahami isu-isu sosial, tetapi juga melakukan sesuatu yang penting berkaitan dengan isu-isu tersebut. Artinya, peserta didik tidak hanya berhenti pada penguasaan materi, tetapi juga terjun langsung di masyarakat untuk menerapkan teori-teori yang mereka peroleh di ruang kelas.

Pelaksanaan yang sering muncul di permukaan dan yang harus segera dicarikan solusi bersama adalah adanya satu persoalan di kalangan para tokoh agama, bahwa mereka mendambakan terwujudnya agama tunggal di muka bumi ini. Padahal hal ini merupakan suatu kemustahilan dan bertentangan dengan "cetak biru" Tuhan. Pemahaman seperti itu akan menjadi penghambat bagi pendidikan berbasis pluralisme yang mengejawantahkan sisi humanis, terbuka, sebagai interpretasi dari aspek teologis. Dengan pemahaman keagamaan yang luas dan terbuka, dapat menciptakan kehidupan yang penuh dengan toleransi yang pada akhirnya menciptakan iklim untuk dapat menahan diri, sekaligus menjembatani jurang stereotip dan kekhawatiran yang terkadang mendominasi kelompok lain.

Sehingga menyebabkan tidak adanya konflik keagamaan antara masyarakat Toraja (Kristen) dan Muslim Kota Palopo, namun sebagian besar merupakan keturunan dari suku

\footnotetext{
${ }^{16}$ Suparman, Dosen PAI dan Pancasila UNANDA, Wawancara, 14 Februari 2019.
} 
Bugis Sulawesi Selatan dapat dilihat dari bagaimana mereka bersama-sama membangun peradaban, yang didasarkan pada dua nilai: sosial dan ekonomi.

Pertama. Nilai Sosial. Wujud dari nilai sosial ini terlihat dalam aktivitas menumbuhkan ikatan silaturrahmi yang kuat. Sejak kedatangannya, masyarakat Muslim di Kota Palopo dan masyarakat Toraja terbiasa untuk saling berkunjung ke rumah masing-masing ketika hari raya keagamaan. Hal ini dilakukan berpangkal dari sejarah gotong royong antara umat Toraja dan Muslim dalam membangun Perguruan Tinggi di Kota Palopo yang tadinya merupakan daerah yang ditumbuhi hutan belantara dan merupakan tempat pembuangan para pembangkang kerajaan di Tana Luwu, menjadi sebuah daerah industri yang sangat maju. Menurut hasil wawancara dengan salah tokoh karismatik di Kota Palopo Andi Sattiaraja bahwa persaudaraan antara komunitas Ikatan Pelajar Mahasiswa Luwu (IPMAL) dan Ikatan Pelajar-Mahasiswa (IPMA) oraja di Kota Palopo, ${ }^{17}$ menjelaskan, bahwa kebiasaan masyarakat di Kota Palopo untuk bersosialisasi dengan masyarakat sangat tinggi. Ini dapat dilihat dari kebiasaan muslim di Kota Palopo beramal jariah dengan tanpa melihat perbedaan agama, sistem kekerabatan ini yang masih tetap terjalin sampai sekarang.

Pluralisme tidak sama dengan sekadar meyakini kemajemukan agama dan toleransi. Orang yang mengerti keanekaragaman agama belum tentu meyakini adanya nilai-nilai kebenaran atau jalan keselamatan pada agama lain. Seseorang yang berada pada posisi ini biasanya masuk dalam kategori kaum eksklusif atau inklusif, tetapi bukan pluralis. Begitu pula, seseorang yang toleran berada dalam dua kategori itu, karena toleransi adalah sikap sosial seseorang yang mau, karena tak ada pilihan lain, hidup berdampingan dengan orang lain yang berbeda agama, meskipun ia tidak setuju atau tidak suka dengan paham keagamaan tetangganya itu. ${ }^{18}$ Seseorang yang toleran dan yang meyakini kemajemukan boleh jadi orang yang memiliki kepedulian sosial dan kemanusiaan yang tinggi dengan orang lain yang berbeda agama, tetapi ia tetap tidak mengakui jalan kesematan pada agama lain.

Kebiasaan-kebiasaan itu semakin menguat ketika bertemu dengan kebiasaan-kebiasaan umat Toraja yang mayoritas Kristen di Kota Palopo yang bersifat adaptif dan adoptif dengan setiap fenomena sosial yang ada. Melalui konsep Siri Pacce', mereka membangun sebuah peradaban yang di bungkus dengan filosofi budaya $4 \mathrm{~S}$. Orang Islam dahulu suka menyantuni anak yatim baik itu warga yang beragama Islam maupun mereka yang beragama Toraja (Kristen) dan sampai saat ini masih tetap terlaksana. Banyak orang-orang Muslim pada saat ini mulai sadar akan berfungsinya dampak bersedekah atau beramal bagi penciptaan kerukunan umat beragama. Cara menyantuninya pun bermacam-macam, diantaranya melalui: memberikan uang, bingkisan, sembako, pakaian dan lain-lain. Sementara umat Toraja (Kristen) dengan kelembutan, kesantunan, dan keterbukaan-nya, memberikan sarana-prasarana (tidak membatasi) bagi umat Muslim untuk beraktivitas dan menunjukkan identitasnya sebagai umat Islam.

Kedua. Nilai Ekonomi. Jika dilihat dari sejarahnya, pada masa sebelum kemerdekaan, profesi kebanyakan masyarakat Toraja yang berdomisili di Luwu, Luwu Utara, bahkan Luwu Timur, berprofesi sebagai petani. Banyak diantara di Luwu utara, seperti suku Jawa merupakan petani yang produktif karena memang asal-usul mereka dari petani. Seiring dengan perkembangan zaman, para petani yang dimotori oleh warga Muslim (Suku Jawa), sekarang banyak melakukan aktivitas perekonomian-nya dalam bidang perikanan dipusatkan di Kecamatan Sukamaju. Mereka melakukan aktivitas perekonomian tersebut tidak hanya kepada warga yang Muslim, tetapi juga

${ }^{17}$ A. Syaifuddin Kaddiraja Opu To Sattiaraja, Kepala Adat di Kecamatan Bua (Wawancara, 27 Januari 2019).

18. Jean L. Mckechnie, ed., Webster's New Twentieth Century Dictionary: Unabridged (USA: William Collins Publishers Inc., 1980), 1919. 
kepada warga yang beragama Toraja (Kristen) yang sebagian besar berprofesi sebagai petani. Bahkan banyak di antara mereka suku Toraja (Kristen) dan orang Bali. ${ }^{19}$

Perbedaan suku, agama, dan ras, juga tidak membatasi mereka dalam melakukan aktivitas perekonomian. Pemukiman transmigrasi Sukamaju hubungan sosial masyarakat multietnik terjalin harmonis, karena masing-masing etnis memahami dan mau menerima budaya etnislain, misalnya etnis Jawa dan Bali yang merupakan penduduk pertama yang datang ke Sukamaju (Tana Luwu), mau menerima dan mengerti kehidupan masyarakat lokal dan berusaha beradaptasi dengan budaya setempat. Akomodasi juga tercipta ketika terjadi pemilihan kepala desa, mereka bersaing secara sehat, masing-masing etnis mengajukan orangorang yang dianggap mempunyai kemampuan untuk menjadi pemimpin dan dapat mengayomi semua etnis yang ada di Luwu. Setiap kelompok etnis berusaha meredam konflik-konflik yang mungkin timbul dalam pemilihan tersebut, sehingga siapa pun yang terpilih akan mendapat dukungan dari semua etnis dalam lingkup masyarakat di Luwu.

Tradisi dilakukan dengan melakukan pelarungan atau menghanyutkan beberapa sesajen berupa kepala hewan berkaki empat seperti, sapi atau kerbau yang dihias sedemikian rupa (bahkan ditambah aksesoris-aksesoris lainnya) ke tengah laut sebagai ucapan terima kasih atau syukur atas hasil tangkapan ikan yang diperoleh oleh para nelayan, sekaligus bertujuan untuk memohon berkah, rezeki, dan keselamatan bagi para nelayan saat melaut. Di Kota Palopo, tradisi ini merupakan suatu tatanan kosmis yang bersifat nyata-tidak nyata yang terbingkai dari ideologi maccera tasi. ${ }^{20}$

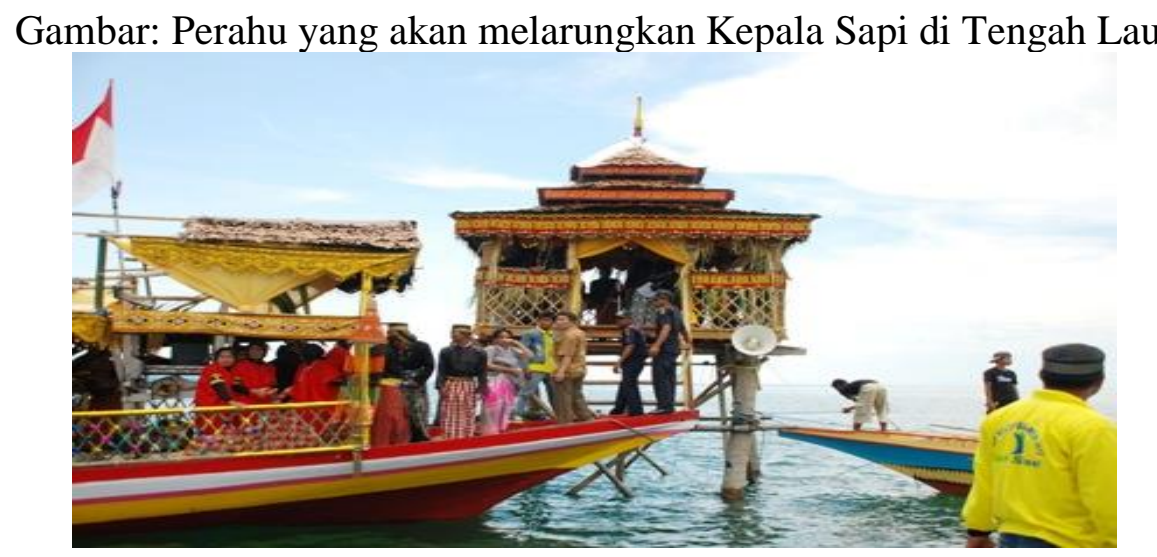

Sumber: Dokumentasi Penulis, 2020

\footnotetext{
${ }^{19}$ Hubungan sosial terjalin melalui kerjasama dalam bidang ekonomi dan sosial, kerjasama berlangsung secara spontan, baik dengan para migran maupun penduduk asli Luwu, yang saat ini hidup rukun dan damai. Masyarakat Sukamaju menyadari betul bahwa mereka datang ke pemukiman transmigrasi di Luwu, seperti Toraja, Bali, Jawa, Lombok.

20 Acara "Pesta Laut" atau Maccera Tasi "adalah salah satu manifestasi Budaya Luwu mengenai hubungan antara ummat manusia dengan "Yang Maha Pencipta" maupun dengan seluruh makhluk hidup dan lingkungan hidupnya di alam ini. Dalam Mythologie I La Galigo disebut bahwa pada masa paling awal (In Illo Tempora), bumi atau "atawareng" ini dalam keadaan kosong dan mati. Tidak ada satupun makhluk hidup yang berdiam dimuka bumi. Keadaan itu digambarkan oleh naskah I La Galigo bahwa tidak ada seekor burungpun yang terbang diangkasa dan tidak ada seekor semutpun yang melata diatas muka bumi ini, serta tidak ada seekor ikanpun yang berenang di dalam lautan dan samudra. Atas usul dari para menteri-menterinya yaitu Balasaariu, Ruma` Makkompong, Sanggiang Pajung, Rukelleng Poba, dan setelah melalui suatu musyawarah antara seluruh DewaDewa Penguasa dari seluruh lapisan alam ini baik dari " Boting Langi" atau Khayangan maupun dari "Toddang Toja" atau dasar samudra yang ketujuh, maka TopalanroE atau Yang Maha Pencipta memutuskan akan menciptakan kehidupan dimuka bumi atau atawareng ini, dengan tujuan agar kelak mereka akan mengucapkan do 'a memohon keselamatan bila mereka ditimpa bencana dan malapetaka dan atau mengucapkan "Doa Syukur" bila mereka mendapat rahmat dan rejeki dari Yang Maha Esa.
} 
Di Kota Palopo, tradisi maccera tasi/pesta laut ini dilakukan oleh dua umat yang berbeda agama, yaitu umat yang beragama Hindu dan umat yang beragama Islam. Bisa dikatakan bahwa tradisi macera tasi yang diadakan di Kota Palopo, Malangke (Tokke), Malangke Barat (Amasangen) dan lain-lain menjadi sarana untuk melakukan komunikasi antar nelayan dengan keyakinan-keyakinan berbeda. Menurut Salik, ${ }^{21}$ tradisi maccera tasi memiliki beberapa fungsi, yaitu: Pertama, Fungsi Individu. Tradisi merupakan suatu institusi kegiatan budaya yang dianggap memiliki fungsi dan andil bagi masyarakat yang dapat mengurangi kecemasan dalam menghadapi hal-hal yang tak dipahami. Fungsi individu dalam pengejawantahan tradisi petik laut ini adalah; persembahan sesajen pada dewa laut untuk memohon keselamatan sebagai bentuk ucapan rasa syukur atas hasil laut yang mereka dapatkan.

Fungsi individu dalam sebuah tradisi, akan memberikan suatu kepuasan diri secara emosional, serta dapat menumbuhkan rasa kepercayaan diri yang basar, sehingga individu yang melakukan suatu ritual, akan merasa lebih aman dan nyaman dibandingkan tidak melakukan ritual. $^{22}$

Kedua, fungsi sosial. Manusia dikatakan sebagai makhluk sosial karena pada diri manusia ada dorongan dan kebutuhan untuk berinteraksi dengan orang lain, yang dalam hidupnya selalu diliputi oleh kebutuhan yang bersifat jasmani dan rohani. Ketiga, fungsi psikologis. Keyakinan yang dianut oleh masyarakat pesisir pantai di Kota Palopo, menjadi alah satu faktor terpenting bagi bertahannya tradisi maccera tasi. Masyarakat Palopo, Malangke, Malangke Barat, mereka tidak berani mengubah atau memotong setiap bagian dari tradisi tersebut. Karena pada dasarnya tradisi yang dilaksanakan itu, dilandasi kepercayaan atau keyakinan masyarakat setempat yang melaksanakan tradisi tersebut. Menurut Ikram, ${ }^{23}$ Pelaksanaan tradisi maccera tasi merupakan tradisi yang dilakukan oleh masyarakat Luwu dan Suku Bugis, namun masyarakat Toraja selalu ikut andil dalam perayaan ini. Melalui tradisi ini, masyarakat yang berbeda keyakinan semakin menumbuhkan rasa kebersamaan serta menumbuhkan rasa kepercayaan serta rasa saling memiliki. Apabila rasa kepercayaan dan rasa saling memiliki antar umat telah tumbuh, maka kemungkinan terjadinya konflik antar umat tersebut sangatlah kecil, sehingga dapat mengantarkan ketentraman dan keharmonisan dalam hidup bermasyarakat.

Dapat dikatakan bahwa tradisi macera tasi, merupakan salah satu wadah atau sarana bagi masyarakat serta pemerintah dalam melakukan komunikasi dan dialog antar umat beragama, yang bertujuan untuk menciptakan kehidupan masyarakat yang harmonis, aman, dan tenteram. Selain mewadahi hubungan antar umat beragama, tradisi ini juga mewadahi komunikasi antara masyarakat dengan pemerintah. Semakin tingginya tingkat keyakinan atau kepercayaan yang terjalin antar kedua umat beragama di Kota Palopo, dapat meminimalisasi terjadinya kesenjangan sosial, serta konflik antar umat beragama. Selain itu, kepercayaan dan rasa kebersamaan sangat berpengaruh dalam menjalin kerukunan antar umat beragama. Selanjutnya, untuk mencegah terjadinya konflik antar umat beragama di setiap daerah, perlu diadakan suatu kegiatan yang bermanfaat serta dapat memberikan dampak positif bagi perkembangan kehidupan beragama.

Kegiatan yang bernuansa kultural di Kota Palopo, terbukti ampuh menciptakan kerukunan antar umat beragama. Beberapa aktivitas warga tidak saja melibatkan masyarakat sipil, tetapi juga melibatkan seluruh aparatur pemerintah. Mereka aktif dalam kegiatan atau aktivitas kultural kemasyarakatan dengan tujuan untuk saling mengenal perbedaan dan untuk saling mengisi kekurangan serta saling tolong-menolong dalam kehidupan bermasyarakat. Kerukunan umat beragam adalah upaya umat beragama dan pemerintah di bidang pelayanan,

\footnotetext{
${ }^{21}$ Salik (W. Ombong), Tokoh Adat (Wawancara, 10 Januari 2019).

${ }^{22}$ Muhammad Yunus, Mahasiswa IAIN Palopo (Wawancara, 27 Januari 2019).

${ }^{23}$ Ikram, Mahasiswa IAIN (Wawancara, 27 Januari 2019).
} 
pengaturan, dan pemberdayaan umat beragama. Dengan demikian, umat beragama bukanlah objek melainkan menjadi subjek dalam upaya pemeliharaan kerukunan, sehingga tidak akan ada konflik yang berujung pada penghilangan nyawa manusia. ${ }^{24}$

Jika ditinjau dalam ajaran agama Islam, jiwa manusia ditempatkan urutan tertinggi. Demi keselamatan jiwa, Allah memperkenalkan sesuatu yang semestinya dilarang. Dalam syariat Islam misalnya, sebuah makanan yang semula haram akan menjadi halal, ketika dalam keterpaksaan, yaitu; ketika kehidupan manusia atau nyawanya terancam, jika tidak mengkonsumsi makanan yang haram itu. Islam sangat peduli dengan keselamatan jiwa manusia, perbuatan yang mengancam keselamatan jiwa adalah musuh utama dari agama ini. Islam juga tidak membedakan dalam kasus melenyapkan satu nyawa dengan melenyapkan banyak nyawa, karena kedua-duanya sama-sama mengancam kedamaian dunia.

Kuatnya prinsip-prinsip pluralisme ini, dikarenakan adanya proses pendidikan penanaman nilai-nilai agama dan budaya secara bersamaan. Sehingga hasil dari model pendidikan seperti ini, tidak terjadi benturan-benturan antara budaya (Islam maupun Toraja) dengan budaya setempat. Dalam ungkapan yang lebih tajam, Pippa Noris dan Ronal Inglehart berargumen bahwa "Cultures does matter-indeed, it matters a lot. Historical religious traditions have left an enduring imprint on contemporary values." Budaya merupakan inti otonom yang menentukan hitam-putihnya kualitas sebuah peradaban, dan di Tana Luwu entitas budaya tersebut, terdapat system of beliefs yang diilhami oleh agama-agama. Ungkapan yang disampaikan oleh Pippa Noris dan Ronal Inglehart, mewujud secara nyata dan aktif dalam aktivitas kehidupan beragama dan berbudaya pada masyarakat di Kota Palopo.

Pendidikan pluralisme yang dimulai dari dalam masing-masing keluarga di Kota Palopo, menghasilkan kesadaran mendalam bagi masyarakatnya, akan adanya perbedaan dalam segala aspek kehidupan. Menurut Ilham, ${ }^{25}$ segala perbedaan tersebut-oleh masyarakat di Kota Palopo-dijadikan sebagai sarana untuk saling tolong-menolong, saling melengkapi, saling mengoreksi, dan saling mengingatkan, yang bertujuan untuk memperkuat padaidi (persaudaraan) dalam berinteraksi sosial di tengah masyarakat di Kota Palopo yang pluralmultikultural.

Menurut Anton Bakker, dalam pembahasan ontologi ada perspektif yang melihat bahwa kesatuan dan perbedaan adalah pertentangan yang tidak dapat didamaikan. Jika disebut bersatu atau kesatuan, maka yang niscaya adalah menjadi satu, tunggal, sama, eka, dan identik, karena itu mustahil sekaligus menjadi banyak, ganda, beraneka dan berbeda. Terhadap masalah ini, ada dua pandangan fundamental yang berusaha mengatasi pertentangan antara kesatuan dan perbedaan. Pertama, adalah monisme, dan kedua adalah pluralisme. Baik monisme maupun pluralisme dapat bersifat spiritualistis atau materialistis. Monisme sendiri terbagi menjadi dua, mutlak dan lunak. Monisme mutlak menghilangkan sedapat mungkin segala kegandaan dan keanekaragaman, sehingga yang ada (tinggal) hanya satu realitas tunggal, entah itu materi seragam atau roh unik. Namun, monisme mutlak mustahil dipertahankan, karena secara de facto hanya terdapat monisme lunak dan tendensi monistik. ${ }^{26}$

Menurut konsep monisme lunak, yang ada hanya satu pengada, entah materi atau roh, yang meliputi keseluruhan kenyataan. Tetapi, untuk mencapai identitas pribadinya, ia harus memuat banyak aspek, atau cara (modus), atau bentuk-penjelmaan, yang semuanya terbatas, berbeda-beda dan berlawanan. Secara bersama-sama dan saling berhubungan, mereka membentuk yang satu itu (atau kesatuan). Meskipun terdapat perbedaan, namun keanekaan

\footnotetext{
${ }^{24}$ Muhammad M. Basyuni, Kebijaksanaan dan Strategi Kerukunan Umat Beragama (Jakarta: Menteri Agama RI, 2006).

${ }^{25}$ Ilham Baderu, Mahasiswa IAIN (Wawancara, 27 Januari 2019).

26 Anton Bakker, Ontologi Atau Metafisika Umum: Filsafat Pengada dan Dasar-Dasar Kenyataan (Yogyakarta: Penerbit Kanisius, 1992), 26-27.
} 
entitas masing-masing tidak bersifat otonom secara mutlak. Mereka hanya sekumpulan kemajemukan yang tidak terbatas jumlahnya.

Kedua, pluralisme juga terbagi menjadi dua, mutlak dan lunak. Pluralisme mutlak sedapat mungkin ingin menghapuskan segala kesatuan dan keseragaman, sehingga yang tinggal hanya kejamakan mutlak, yaitu pecahan-pecahan material atau titik-titik rohani. Setiap entitas (pengada) bersifat otonom secara mutlak, tanpa kesatuan apa pun dengan yang lain. Tetapi, pluralisme mutlak mustahil dipertahankan, karena secara de facto hanya terdapat pluralisme lunak dan tendensi pluralistik. Menurut pluralisme lunak, pada intinya kenyataan bersifat jamak, beraneka ragam, dan terdiri dari unit-unit yang serba otonom dan tanpa hubungan intrinsik. Namun, agar perbedaan dan kegandaan itu benar-benar menjadi suatu pertentangan dan perbandingan antara satu dengan yang lain, maka dibutuhkan satu rangka kesatuan riil.

Pelaksanaan kearifan lokal (local wisdoms) berbasis nilai-nilai lokal di Perguruan Tinggi merumuskan filsafat pendidikan Islam yang bersumber dari al-Qur'an, Proses pembentukan karakternya dapat dikelompokkan menjadi empat aliran yaitu: (1) fatalisme-pasif (2) netralisme-pasif (3) positivisme-aktif dan (4) dualisme-aktif. ${ }^{27}$ Sementara itu menurut Morris L. Bigge mengemukakan bahwa ada empat sifat dasar manusia dan hubungannya dengan alam sekitar yaitu badactive (jelek-aktif), good-active (baik-aktif), neutral-passive (netral-pasif) dan neutral interactive (netral-interaktif). ${ }^{28}$ Pertama, yang memiliki pandangan fatalisme-pasif, mempercayai bahwa setiap individu karakternya kuat-positif atau lemahnegatif melalui ketetapan dari Allah SWT secara asal baik itu ketetapan semacam yang terjadi secara semuanya atau sebagian saja. Faktor-faktor eksternal termasuk pendidikan tidak begitu berpengaruh, karena setiap individu terikat dengan ketetapan yang telah ditentukan sebelumnya. Ketetapan itu dapat dialirkan kepada hereditas (gen) seseorang secara kodrati. Seorang pendosa (berkarakter lemah-negatif) akan masuk surga jika hal itu menjadi nasibnya (given). Sifat dasar ini tidak berubah yakni berkaitan dengan karakter seseorang untuk masuk neraka atau masuk surga. Kebahagiaan atau penderitaan, atau berkarakter kuat-positif atau lemah-negatif. Implikasi dari pandangan ini bahwa faktor eksternal termasuk lingkungan dan pendidikan adalah pasif dalam pembentukan karakter. Karena itu karakter kuat positif atau lemah-negatif telah ditentukan lebih dulu sebelum seseorang lahir ke dunia.

Dalam konteks menghadapi kemajemukan agama dan keyakinan, para sarjana agama, terutama dari kalangan Kristen, telah sejak lama merumuskan tipologi respons para pemeluk agama. Yang paling terkenal diantaranya adalah tiga model: eksklusivisme, inklusivisme, dan pluralisme.

Karakter kuat dan posistif itu bersifat dinamis dan aktif mempengaruhi lingkungan sekitar. Jika terdapat seseorang berkarakter lemah-negatif, hal itu bukan dari cetak biru Tuhan, dan bukan pula bagian integral dari dirinya. Tetapi hal itu berasal dari luar dirinya yang sifatnya sementara dan menumpang dalam diri seseorang. Seperti halnya pohon benalu menumpang tumbuh di pohon mangga. Pohon mangga tidak akan berubah menjadi pohon benalu. Sebaliknya pohon benalu tidak akan berubah menjadi pohon mangga. Justru yang terjadi adalah pohon mangga (karakter kuat-positif) hidup tertatih-tatih bahkan mati sebelum ajal yang sesungguhnya, karena digerogoti secara istiqamah oleh pohon benalu (karakter lemah-negatif).

Karena itu menurut William Kilpatrick bahwa salah satu penyebab ketidakmampuan seseorang berlaku baik meskipun ia telah memiliki pengetahuan tentang kebaikan itu adalah karena ia tidak terlatih (terbiasa) untuk melaksanakan kebaikan itu. Menurut penelitian oleh Patricia Zahira Salahuddin, hasil temuannya menjelaskan bahwa Pendidikan karakter menggunakan sifat bervariasi dan perilaku yang diharapkan, Lembaga pendidikan memberikan

\footnotetext{
${ }^{27}$ Maragustam, Mencetak Pembelajar Menjadi Insan Paripurna; Falsafah Pendidikan Islam (Yogyakarta: Nuha Litera, 2010), 92-98.

${ }^{28}$ Morris L. Bigge, Learning Theories for Teachers (USA: Harper and Row, Publisher, Inc, 1982), 16.
} 
kurikulum pendidikan karakter terutama melalui mata pelajaran/mata kuliah studi Islam/Pendidikan Agama Islam, sehingga penekanan lembaga pendidikan pada nilai-nilai moralitas dan spiritual berperan dalam karakter pengajaran mereka. ${ }^{29}$

Membangun persaudaran atas dasar perbedaan budaya tentu tidaklah mudah. Dibutuhkan kegigihan dan motivasi kuat dalam menjalankan misi suci tersebut. Oleh karena itu, seharusnya alumni sekolah lintas iman ini harus tetap "in contact" ${ }^{30}$ menjaga hubungan baik dengan beberapa kelompok lintas budaya, baik yang se-visi maupun yang menolak ide besar dari komunitas lintas iman itu sendiri. Pengembagan jejaring budaya harus tetap dirawat dan disemai untuk menjaga konsistensi dalam memperjuangkan nilai-nilai pluralisme agama di tengah-tengah masyarakat.

Selain itu pelaksanaan pendidikan kearifan lokal yang lebih kontributif dan praktis di tengah-tengah masyarakat yang berkontribusi secara efektif pada usaha memajukan toleransi, dan menghormati hak-hak yang sama terhadap kebebasan beragama atau berkeyakinan dari semua individu yang dididik. ${ }^{31}$ Inti dari apa yang dikemukakan oleh Plesner memuat dua uraian utama, yaitu efektivitas dalam memajukan toleransi dan penghormatan terhadap kebebasan beragama dan berkeyakinan.

Mahasiswa diarahkan untuk secara aktif memajukan toleransi dan penghormatan terhadap keyakinan orang lain. Hal ini dilakukan agar individu mahasiswa dapat merefleksikan kedua target tersebut dalam kehidupan sehari-hari di masyarakat. Perubahan individu peserta didik yang konstruktif dapat menjadi cikal bakal lahirnya kehidupan keberagamaan yang penuh penghormatan terhadap perebedaan. Pada tahap ini, diharapkan dapat menciptakan ikatan keragaman yang saling menguatkan, saling mendukung, dan menghormati satu sama lain yang tercakup konsep sipakatau, sipakalebbi, sipakaingge.

Pendidikan harusnya didasarkan pada basis pengalaman mahasiswa masing-masing. Setiap mahasiswa bebas mengeksplorasi pengalaman keberagamaannya, tanpa harus merasa terintimidasi dengan pengalaman keberagamaan orang lain. Oleh karena itu, di sinilah pentingnya pendidikan pluralisme. Sebab, pendidikan pluralisme menekankan aspek lesson learning, tidak cukup hanya menghapalkan agama-agama dan budaya formal di Indonesia saja. Untuk membuat pembelajaran agama model hapalan ini gampang, tetapi proses pedagogics yang ingin dicapai tidak tersentuh, apalagi kalau penilaian akhirnya berbasis angka. Seharusnya pendidikan agama didasarkan pada sejauh mana seorang peserta didik bisa mengespresikan, mengalami langsung, dan mentransformasikan keyakinan keagamaanya dalam kehidupan sehari-hari. Perubahan pemahaman mahasiswa dari prasangka menjadi penghargaan dan apresiasi posistif terhadap tradisi budaya lain. Pendidikan kearifan lokal tidak memberi ruang bagi peserta didiknya untuk bisa melakukan konversi agama/budaya.

Ikram menjelaskan, bahwa sebagian besar merasa beruntung mengikuti kuliah di IAIN Palopo, dan mereka mempunyai presepsi positif terhadap budaya Toraja dan Rongkong, Jawa bahkan Sasak. ${ }^{32}$ Di samping itu relasi budaya dalam dimensi visi misi IAIN Palopo adalah

29 Patricia Zahira Salahuddin, Character Education in A Muslim School: A Case Study of A Comprehensive Muslim School's Curricula, Dissertation, Florida International University, 2011.

${ }^{30}$ Amrina R. Wijaya, "How Indonesian School System Segregates Believers", https://magdalene.co/story/how-indonesian-school-system-segregates-believers, Diakses 12 Maret 2021. Bandingkan dengan Anna Halafoff, "Social Movements, Cosmopolitanism and Multifaith Engagement" The Multifaith Movement: Global Risks and Cosmopolitan Solutions (Springer Netherlands, 2013), 9-34.

${ }^{31}$ Ingvill Thorson Plesner, "Promoting Tolerance Through Religious Education" Facilitating Freedom of Religion or Belief: A Deskbook. (2004), 648.

32 Suku Jawa, Bali, dan Lombok, Bugis merupakan dan Toraja masyarakat multietnik di pemukiman transmigrasi Kecamatan Sukamaju yang merupakan pemekaran dari Kecamatan Bone-Bone Kabupaten Luwu Utara. Transmigran yang ada di Sukamaju berasal dari berbagai etnis. Hal ini menyebabkan keanekaragaman etnis dan budaya di daerah pemukiman transmigrasi di Sukamaju. Keanekaragaman etnis dan budaya tersebut akan 
penguatan pada aspek personal, dengan meyakini bahwa budaya kita sama, bahwa dalam konteks ajaran sebagai sebuah "kotak makanan" tentu kita berbeda, tetapi pada aspek prinsipil dalam bentuk Isi kotak tersebut adalah kita sama. Proses penghayatan iman dapat mencairkan kebekuan keberagamaan kita selama ini, tentu dalam hal ini kita harus banyak menghayati budaya dalam domain atau aspek spritulitas. ${ }^{33}$

Kekuatan budaya yang tercermin dari modal utama dalam membangun relasi sosiologis di tengah umat yang berbeda agama dan budaya. Paling tidak inilah yang bisa dipahami dari komentar Ikram di atas. Kesadaran personal yang diterangi oleh sinar iman kebenaran, tentu akan melahirkan kesadaran sosiologis yang berimplikasi pada terciptanya hubungan yang harmonis di antara pemeluk agama yang berbeda keyakinan. ${ }^{34}$ Pada kondisi ini akan tercipta strengthening at the micro-level of society ${ }^{35}$ sebuah kekuatan-pemahaman dalam wilayah mikro-sosial. Kekuatan pemahaman dan penerimaan tulus akan adanya perbedaan inilah yang menjadi modal besar untuk mengubah struktur sosial yang lebih luas dengan jangkauan yang massif.

Peran sosial-budaya seseorang tentu hanya bisa diukur dari sejauh mana ia bisa menjadi bermanfaat bagi kepentingan kemanusian. Agama tentu tidak bisa abai terhadap kenyataan social. Agama dan budaya harus mampu memberi solusi dan hadir menyapa fenomena tersebut. Sebab semua ajaran agama mengajarkan tentang pentingnya berbuat baik kepada sesama manusia. Tentu, tanpa harus mempertimbangkan status dan identitas manusia tersebut. Pendidikan kearifan lokal Bugis, paling tidak bisa merubah cara pandang para mahasiswa dalam melihat fenomena pluralis di tengah-tengah masyarakat.

Pada prinsipnya pendidikan kearifan lokal diterapkan di kampus memang memberi pemahaman yang utuh kepada mahasiswa untuk bisa deeply respects the cultural, faith, religious, or secular, ${ }^{36}$ senantiasa memperdalam respek dan perhatian terhadap hal-hal yang berhubungan dengan keyakinan, agama, dan fenomena sosial. Pada sisi yang lain, komentar salah seorang lulusan UNANDA perlu menjadi perhatian. Ia mengatakan bahwa pengaruh secara sosial bisa dilihat dari lulusannya ketika mereka kembali ke masyarakat. Mereka bisa mengkampanyekan hidup damai di tengah-tengah perbedaan keyakinan di masyarakat. Menjadi penggerak terhadap kemajuan umat beragama, serta bisa menjadi penengah terhadap problem keagaman yang bisa berakibat terjadinya konflik antar agama dan budaya. ${ }^{37}$ Menjadi penggerak terhadap kemajuan umat beragama serta penengah atas timbulnya gesekan keagamaan. Harus menjadi visi hidup kampus ini. Apa yang telah didapatkan selama mengikuti kuliah di kampus. Ini bisa menjadi bekal untuk membangun sinergitas antar umat beragama. Para alumni ini

mempengaruhi hubungan social dalam kelompok masyarakat di manapun berada, termasuk di pemukiman transmigrasi. Abdul Hafd, Hubungan Sosial Masyarakat Multietnik di Kabupaten Luwu Sulawesi Selatan, Jurnal “Al-Qalam, Volume 22 Nomor 1 Juni 2016, 257-268.

${ }^{33}$ Wawancara bersama Ikram (mahasiswa IAIN), pada tanggal 16 Februari 2019.

${ }^{34}$ Kontak atau pertemuan dua etnis atau lebih di daerah pemukiman transmigrasi akan menimbulkan dua kemungkinan, yaitu yang bersifat positif dan yang bersifat negatif sebagai perwujudan dari proses interaksi. Akan menimbulkan positif apabila mereka mampu menciptakan suasana hubungan sosial yang harmonis di daerah tujuan mereka. Kemudian sebaliknya akan muncul hal yang bersifat negatif apabila masing-masing etnis tidak mampu memahami budaya etnis lain yang ada di sekitar mereka, sehingga menimbulkan banyak potensi konflik, Nelvia Gustina, "Proses Sosial Antar Kelompok Etnis di Pemukiman Transmigrasi Spontan (Kasus pada Pakon Marang Kecamatan Pesisir Selatan Kabupaten Lampung Barat Provinsi Lampung) dalam Fakultas Pertanian. Institut Pertanian Bogor, 2002).

${ }^{35}$ Sheila C. Gordon dan Benjamin Arenstein, “Interfaith Education: A New Model for Today’s Interfaith Families", (Springer Science+Business: Media Dordrecht and UNESCO Institute for Lifelong Learning, 2017), 192.

${ }^{36}$ Brendan Carmody, "Interreligious Education and the Question of Truth" in Kath Engebretson, etl., International Handbooks of Religion and Education, (Springer Science+Business Media B.V. 2010), 50.

${ }^{37}$ Wawancara Salwan Soean, pada tanggal 14 Februari 2019. 
diharapakan tidak hanya sekedar melakukan replicate-mereplikasi ulang realitas sosial-budaya, tetapi, bisa melakukan recreate-menata ulang bangunan sosial-budaya yang cenderung tidak ramah terhadap adanya perbedaan budaya atau agama. ${ }^{38}$

Toleransi beragama kedengarannya menjadi hal yang biasa saja. Tetapi, praktik pelaksanaanya kadangkala menghadapi berbagai macam kendala. Peran umat Muslim dalam bertoleransi dengan pemeluk agama lain seperti orang mahasiswa Seko dan Saudara Kita dari Tator (Tau Toraja).

Pandangan keagamaan sesungguhnya dapat menjadi modal teologis-filosofis bagi berkembangnya kerukunan aktif di antara agama dan suku di tanah air. Kerukunan aktif tidak semata dimaknai sebagai hubungan antar umat beragama yang dilandasi toleransi dan saling menghormati semata, tetapi juga pengakuan adanya kesetaraan dalam pengalaman dan pengamalan ajaran, adanya proses saling belajar untuk memperkaya pengalaman keagamaan masing-masing dengan tidak mengorbankan keyakinan (akidah) tiap-tiap individu. Modal agama tetap relevan dan signifikan serta berada dalam momentum yang tepat ketika perbedaan di negeri ini seringkali dianggap sebagai ancaman yang harus dimusnahkan daripada rahmat yang harus disyukuri dan aset bangsa serta wahana untuk menciptakan ruang dialog yang terus menerus.

\section{Penutup}

Kota Palopo bukan hanya masyarakat Luwu, tetapi banyak suku seperti Bali, Jawa, Toraja, Makassar dan Bugis. Pengetahuan terhadap budaya lain sangat dibutuhan saat ini. Pengetahuan dan pemahaman terhadap tradisi budaya masyarakat yang mengandung nilai pluralism memungkinkan mahasiswa untuk bisa menunda kecurigaan, atau bahkan hilang sama sekali, tentang hal-hal negatif yang selama ini dipahami oleh mahasiswa terhadap agama lain. Konsep pluraslisme dilihat dari implementasikan dari filosofi budaya di Kota Palopo Sipakatau, Sipakalebbi dan Sipakaingge yang menunjukkan bahwa nilai kearifan local terejawantahkan di institusi di Palopo yaitu IAIN Palopo dan Univeristas Andi Djemma.

Studi ini membuktikan bahwa secara personal mahasiswa yang terlibat aktif di dalam pelaksanaan pendidikan kearifan lokal ini merasa mengalami perubahan yang. Pada aspek iman, mereka semakin yakin dengan agamanya sendiri, sembari tetap memberi ruang yang adil terhadap penilaian yang baik dan benar terhadap kebenaran ajaran keyakinan agama dan budaya lain. Selanjutnya pada sisi metodologis, pendidikan kearifan lokal mengembangkan karakter (1) fatalisme-pasif (2) netralisme-pasif (3) positivisme-aktif dan (4) dualisme-aktif, yang menyebabkan. Pada aspek sosiologis, meskipun tidak berpengaruh secara massif yang dirasakan oleh umat beragama, tetapi paling tidak pelakasnaan pendidikan kearifan lokal pada perguruan tinggi ini bisa memberi efek positif bagi perkembangan hubungan antar agama/budaya di Indonesia di masa depan.

\section{Daftar Pustaka}

Abdullah, Taufik, "Adat and Islam: An Examination of Conflict in Minangkabau", Indonesia, No. 2 (1966):

Asyanti, Setia, Pendidikan karakter di perguruan tinggi: Sudah terlambatkah? Prosiding Seminar Nasional Psikologi Islami, Surakarta, 21 April 2012.

Bakker, Anton, Ontologi Atau Metafisika Umum: Filsafat Pengada dan Dasar-Dasar Kenyataan, Yogyakarta: Penerbit Kanisius, 1992.

Basyuni, Muhammad M., Kebijaksanaan dan Strategi Kerukunan Umat Beragama Jakarta: Menteri Agama RI, 2006.

\footnotetext{
${ }^{38}$ Davies, "Religious Education and Social Literacy: the 'white elephant' of Australian Public Education" British Journal of Religious Education, (2017), 8.
} 
Bellah, Robert N. dan Phillip E. Hammond, Varieties of Civil Religion, Yogyakarta: IRCiSoD, 2003.

Bigge, Morris L., Learning Theories for Teachers, USA: Harper and Row, Publisher, Inc, 1982.

Bustaman, Kamaruzzaman -Ahmad, "Contemporary Islamic Thought in Indonesia and Malay World: Islam Liberal, Islam Hadhari, and Islam Progresif”, Journal of Indonesian Islam, Vol. 5, (1) (June 2011): 91.

Carmody, Brendan, "Interreligious Education and the Question of Truth" in Kath Engebretson, etl., International Handbooks of Religion and Education, Springer Science+Business Media B.V. 2010.

Davies, "Religious Education and Social Literacy: the 'white elephant' of Australian Public Education" British Journal of Religious Education, 2017.

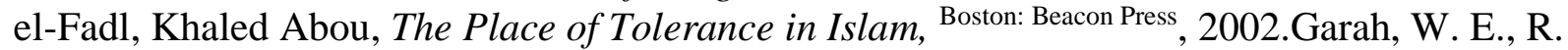
I. Beekun, A. Habisch, G. Lenssen, C. L. Adaui, "Practical Wisdom for Management from the Islamic Tradition”, Journal of Management Development, 31, (10), (2012).

Gordon, Sheila C. dan Benjamin Arenstein, "Interfaith Education: A New Model for Today's Interfaith Families", Springer Science+Business: Media Dordrecht and UNESCO Institute for Lifelong Learning, 2017.

Gustina, Nelvia, "Proses Sosial Antar Kelompok Etnis di Pemukiman Transmigrasi Spontan (Kasus pada Pakon Marang Kecamatan Pesisisr Selatan Kabupaten Lampung Barat Provinsi Lampung) dalam Fakultas Pertanian. Institut Pertanian Bogor, 2002.

Hafd, Abdul, Hubungan Sosial Masyarakat Multietnik di Kabupaten Luwu Sulawesi Selatan, Jurnal “Al-Qalam, Volume 22 Nomor 1 Juni 2016.

Halafoff, Anna, "Social Movements, Cosmopolitanism and Multifaith Engagement" The Multifaith Movement: Global Risks and Cosmopolitan Solutions Springer Netherlands, 2013.

HR. Stiff-William, Widening Lens to Teach Character Education Alongside Standart Curriculum. Abstract. The Clearing House, Vol 83. (4) (2010).

Jean L. Mckechnie, ed., Webster's New Twentieth Century Dictionary: Unabridged, USA: William Collins Publishers Inc., 1980.

Kali>n, Ibrahim, "Masa $>$ dir al-Tasa $>$ muh\}, wa'adam al-Tasa $>$ muh fi al-Islam", Majalah Adyan (2009).

Maragustam, Mencetak Pembelajar Menjadi Insan Paripurna; Falsafah Pendidikan Islam, Yogyakarta: Nuha Litera, 2010.

Matthes, B. F., Boeginesche Chrestomathie, Amsterdam: 1859.

--------, Over de Ada's of Gewoonten der Makassaren en Boegineezen, th.

Moschis, George P., Fon Sim Ong, Masoud Abessi, Takako Yamashita, dan Anil Mathur, "Cultural and Sub-Cultural Differences in Reliability", Asia Pacific Journal of Marketing and Logistics, Vol. 25, (1) (2013).

Mulyani, Sri, "Islam, Adat, and the State: Matrifocality in Aceh Revisited", Journal of Islamic Studies al-Jamiah, Vol. 48, (2) (2010/1431).

Muhammadiyah, Hilmi, Perempuan Bugis Naik Haji-Sebuah Tinjauan Antropologis, Depok: Elsas, 2009.

Plesner, Ingvill Thorson, "Promoting Tolerance Through Religious Education" Facilitating Freedom of Religion or Belief: A Deskbook. 2004.

Rais, Za'im, “The Minangkabau Traditionalists' Response to The Modernist Movement”, disertasi, Montreal: McGill University, 1994.

Saidi, Saleh et al., eds., Sejarah Keberadaan Umat Islam di Bali, (Denpasar: MUI, 2002. 
Salahuddin, Patricia Zahira, Character Education in A Muslim School: A Case Study of A Comprehensive Muslim School's Curricula, Dissertation, Florida International University, 2011.

Schwartz, It's Not to Late to Teach College Student about Values. The Chronicle of Higher Education. Vol 46. (40), (2000).

Sheetal R. Shah, The Impact of Acculturation and Religion on Intergenerational Family Conflict for Second Generation Asian Indian Americans, Tesis, Carbondale: Southern Illinois University, 2006.

Sila, "Adlin, Memahami Spektrum Islam di Jawa", Indonesian Journal for Islamic Studies Studia Islamika, Vol. 18, (3), (2011).

Syukri, Peran Pendidikan di Perguruan Tinggi terhadap Perubahan Perilaku Kaum Intelektual (sosial-Individu). Jurnal Ilmiah Kreatif, Vol 6 (1), (2009).

Todd, Stephen dan Andrew Steele, "Modelling a Culturally Sensitive Approach to Fuel Poverty", Structural Survey, Vol. 24, (4), (2006).

Watzlawik, Meike, "Cultural Identity Markers and Identity as a Whole: Some Alternative Solutions", Culture and Psychology, Vol. 18, (2), (2012).

Wijaya, Amrina $R$, "How Indonesian School System Segregates Believers", https://magdalene.co/story/how-indonesian-school-system-segregates-believers, Diakses 12 Maret 2021.

Wynne, E. A., and K. Ryan. Reclaiming our schools: A handbook on teaching character, academics, and discipline, New York: Merrill, 1993.

Yunus, Y., \& Mukhlisin, Sosial-Budaya: Harmonisasi Agama Dan Budaya Dalam Pendidikan Toleransi. Kalam: Jurnal Agama Dan Sosial Humaniora, 8(2), (2020). 1-26. 